\title{
PERUBAHAN FUNGSI PERTUNJUKAN WAYANG GOLEK PURWA DARI SAKRAL KE PROFAN PADA SYUKUR LAUT PAMAYANGSARI
}

\author{
The Change In The Function Of The Purwa Puppet Show From Sacred To Profan In Gratitude Of The \\ Sea Pamayangsari
}

\author{
Fipih Fauziah, Cahya, Neneng Yanti Khozanatu Lahpan \\ fipihfauziah97@gmail.com \\ Prodi Antropologi Budaya, Fakultas Budaya dan Media \\ Institut Seniu Budaya Indonesia Bandung
}

Artikel diterima: 02 Februari 2021 || Artikel direvisi: 22 Februari 2021 || Artikel disetujui: 01 Maret 2021

\begin{abstract}
ABSTRAK
Tradisi syukur laut sudah ada sejak tahun 1975, diisi dengan ritual pelarungan jempana dan diakhiri pertunjukan wayang golek purwa. Fungsi awal sebagai media ruwatan berubah menjadi hiburan. Perubahan tersebut menarik perhatian untuk diteliti. Dengan rumusan, bagaimana struktur dan perubahan fungsi pertunjukan wayang. Adapun tujuan penelitian yaitu ingin mendeskripsikan struktur pertunjukkan dan perubahan fungsinya tersebut.

Penelitian ini menggunakan metode kualitatif, dengan tahapan pengumpulan data menggunakan teknik observasi partisipan, wawancara, dan studi dokumentasi. Kemudian, pengolahan data membuat transkrip hasil pengamatan dan wawancara mendalam. Selanjutnya, dianalisa dengan teori fungsionalisme Malinowski.

Hasil penelitian ini adalah telah terjadi perubahan fungsi pertunjukkan wayang golek purwa dari sakral menjadi profan/hiburan, disebabkan oleh berubahnya sistem kepercayaan masyarakat, cara berpikir modern, kebutuhan masyarakat akan hiburan, adanya konflik, bencana alam tsunami, dan pengaruh kebudayaan luar, serta didukung oleh sponsor dan anjuran dari Bupati Kabupaten Tasikmalaya untuk menghilangkan unsur sesaji.
\end{abstract}

Kata Kunci: Wayang, Sakral, Profan, dan Syukur Laut.

\section{ABSTRACT}

The tradition of sea gratitude has existed since 1975, filled with jempana rituals and ending with the purwa puppet show.It's initial function as a medium for ruwatan turned into entertainment. These changes attract attention to research. With the formulation, how the structure and function changes of wayang performances. The research objective is to describe the structure of the performance and changes in its function.

This research uses qualitative methods, with the stages of data collection using participant observation techniques, interviews, and documentation studies. Then, data processing makes transcripts of observations and in-depth interviews. Furthermore, it is analyzed by Malinowski's theory of functionalism.

The results of this study are that there has been a change in the function of the purwa puppet show from sacred to profane / entertainment, caused by changes in people's belief systems, modern ways of thinking, people's needs for entertainment, conflicts, natural disasters, tsunamis and external cultural influences, as well as being supported by sponsorship and advice from the Regent of Tasikmalaya Regency to eliminate the element of offerings.

Keywords: Wayang, Sacred, Profan, and Gratitude for the Sea 


\section{PENDAHULUAN}

Fenomena kebudayaan merupakan entitas yang bersifat dinamis, yang selalu berkembang dan tentunya mengalami perubahan. Terjadinya proses perkembangan dan perubahan kebudayaan, akan terus berlangsung karena dipengaruhi adanya dinamika internal. Selain itu kebudayaan berkembang dan berubah karena adanya pengaruh-pengaruh eksternal, yang terjadi karena semakin meningkatnya kemajuan ilmu pengetahuan dan teknologi komunikasi.

Demikian pula kesenian yang merupakan bagian dari entitas dinamika kebudayaan, kini telah dan sedang mengalami fase perubahan sebagai bagian dari perkembangan kesenian dengan sistem tradisinya masingmasing.

Seperti halnya mengenai perubahan pada genre kesenian tradisi, dalam hal ini adalah seni pertunjukan wayang golek purwa pada pesta syukur laut di pantai Pamayangsari Desa Cikawungading Kecamatan Cipatujah Kabupaten Tasikmalaya pada saat ini telah mengalami perubahan fungsi dan bentuk dalam pertunjukannya.

Sebagaimana yang kita tahu, bahwa tradisi yang berkembang di masyarakat nelayan Pamayangsari yang hingga saat ini masih memiliki tradisi syukur laut, melibatkan seni pertunjukan wayang golek purwa sebagai bagian yang tak terpisahkan di dalamnya.

Menurut sumber-sumber terkait perihal awal mulanya tradisi tersebut berlangsung, bahwa pertunjukan wayang golek purwa ini sudah ada sejak tahun 1975 sampai sekarang. Kedudukan pertunjukan wayang golek purwa pada saat itu berfungsi sebagai media dalam ruwatan laut. Ruwatan adalah upacara yang dilakukan dalam rangka mencari keberuntungan dengan cara-cara tertentu dan tujuan yang beragam (Pamungkas, 2008: 8).

Sejak tahun 2006 prosesi pelarungan jempana tidak selengkap tahun-tahun sebelumnya yaitu berisi sesaji terdiri dari bunga tujuh rupa, kepala hewan ternak atau sapi, munding bule atau kepala kambing hitam yang dibungkus kain putih. Pelarungan tersebut hanya simbolis yaitu dengan jempana kosong. Perubahan tersebut dikarenakan sebagian besar masyarakat nelayan Pamayangsari khususnya, umumnya masyarakat Desa Cikawungading menganggap sesaji adalah suatu bentuk budaya yang tidak selaras dengan ajaran syariat Islam.

Pada tahun 2006, perubahan hilangnya ritual-ritual seperti pelarungan jempana, ruwatan dan sebagainya berdasarkan hasil musyawarah bersama antara tokoh adat, ketua Rukun Nelayan Pamayangsari, anggota Rukun Nelayan Pamayangsari, para tokoh agama, dan aparat pemerintah setempat mengenai dihilangkannya sesaji dan diganti dengan upacara adat biasa tanpa menyertakan unsur sesaji di dalamnya. Sikap dan pandangan inilah yang menjadikan salah satu penyebab pudarnya keyakinan masyarakat dalam menyikapi sebuah tradisi ritual karena berbagai faktor yang melingkupinya. Selain faktor tersebut, perubahan fungsi pertunjukan wayang dipengaruhi oleh arus globalisasi yang menyebabkan dampak ke berbagai aspek termasuk aspek kebudayaan, sehingga menyebabkan perubahan paradigma masyarakat terhadap ritual ruwatan.

Pada perkembangan selanjutnya, terutama ketika memasuki era teknologi dan informatika, maka fungsinya berubah secara perlahan dari sakral menjadi profan. Perubahannya tampak pada format atau struktur pertunjukannya serta aura suasana penonton yang terbangun dalam sebuah ruang dan waktu berlangsungnya pertunjukan wayang.

Penelitian yang terkait tentang perubahan fungsi ditemukan dalam penelitian Sri Nugrahaeni Puspaningrum (2016) tentang kesenian jepin, Inggit Fernandes (2013) tentang kesenian enggreng, Andri Fitrianto (2013) tentang kesenian reog Banjarharjo. Fryhastyayu Bintyar (2017) tentang seni pertunjukan tari opak abang. Kemudian penelitian yang terkait tentang tradisi ditemukan dalam penelitian Ali Wildan (2015) tentang sedekah laut dalam etika ekologi Jawa, Adiba Zahrotul Wildah (2018) 
tentang ritual baritan (sedekah laut). Selanjutnya penelitian yang terkait tentang seni pertunjukan wayang golek ditemukan dalam penelitian Barnas Sabunga, Dasim Budimansyah, dan Sofyan Sauri (2016) tentang nilai-nilai karakter, serta dalam penelitian Fathimatuz Zahroh (2015) tentang pendidikan nilai.

Dari berbagai penelitian tersebut, penelitian tentang Perubahan Fungsi pertunjukan Wayang Golek Purwa dari Sakral ke Profan pada Pesta Syukur Laut belum diteliti. Maka, penulis merasa tertarik untuk mengangkatnya sebagai objek penelitian dalam perspektif Antropologi Budaya. Fokus penelitian yang dilakukan akan mengkaji dalam tataran terjadinya perubahan fungsi pertunjukan wayang golek purwa dari sakral ke profan pada pesta syukur laut di Pamayangsari Desa Cikawungading.

Dari hasil mencermati terhadap persoalan-persoalan pokok yang akan dijadikan fokus dan aspek pengkajian, maka perlu dirumuskan dalam bentuk pertanyaan penelitian sebagai berikut:

1. Bagaimana struktur pertunjukan wayang golek purwa pada pesta syukur laut di pantai Pamayangsari?

2. Bagaimana perubahan fungsi pertunjukan wayang golek purwa dari sakral ke profan pada pesta syukur laut di pantai Pamayangsari?

Adapun tujuan penulis dalam melakukan penelitian ini adalah:

1. Ingin mendeskripsikan struktur pertunjukan wayang golek purwa pada pesta syukur laut di pantai Pamayangsari.

2. Ingin mendeskripsikan bagaimana perubahan fungsi pertunjukan Wayang golek purwa dari sakral ke profan pada pesta syukur laut di pantai Pamayangsari.

Hasil penelitian ini secara teoretis diharapkan dapat memberikan sumbangan pemikiran dalam memperkaya wawasan ilmu Antropologi, khususnya mengenai pergeseran fungsi
Fipih, Cahya, Neneng - Perubahan Fungsi Pertunjukan.....

wayang golek purwa dalam pesta syukur laut di pantai Pamayangsari. Dan secara praktis diharapkan dapat menjadi sumber penelitian bagi penelitian lanjutan tentang pemecahan masalah yang berkaitan dengan masalah pergeseran fungsi wayang golek purwa dalam pesta syukur laut di pantai Pamayangsari. Sedangkan untuk masyarakat, diharapkan dapat menambah pengetahuan masyarakat tentang seni pertunjukan wayang golek purwa dan dapat lebih menghargai segala bentuk seni sebagai warisan leluhur yang layak dilestarikan.

\section{METODA}

Penulis menggunakan metode penelitian kualitatif yang sangat bermanfaat memperoleh data yang kaya dan sarat deskriptif yang mesti ditafsirkan lewat sejumlah identifikasi berikut pengkodean tema dan kategori yang bermaksud menemukan temuan-temuan yang dapat memberi kontribusi terhadap pengetahuan teoretik dan praktis (Boije 2010 dikutip dalam Setyobudi 2020: 19). Sasarannya pada latar dan individu secara holistik (utuh), tanpa mengisolasi individu atau organisasi menjadi variabel atau hipotesis, ia harus dipandang sebagai bagian dari suatu keutuhan (Bogdan, Robert, dan Taylor, 1992: 5).

Selanjutnya, dalam metode penelitian kualitatif ini, penulis melakukan sejumlah prosedur penelitian, yaitu: teknik pengumpulan data, teknik pengolahan data, teknik analisis data, dan teknik penyajian data.

1. Teknik Pengumpulan Data. Teknik pengumpulan data dalam penelitian ini yaitu: observasi partisipasi, wawancara, dan studi dokumentasi.

2. Teknik Pengolahan Data.Tahapan selanjutnya setelah pengumpulan data yaitu pengolahan data. Metode/teknik/cara pengolahan data pada penelitian kualitatif adalah membuat transkrip (verbatim) dari seluruh hasil pengamatan dan wawancara mendalam. 
3. Teknik Analisis Data

Analisis data dalam penelitian kualitatif dilakukan sejak sebelum memasuki lapangan, selama di lapangan, dan setelah selesai dari lapangan.

Dalam penelitian kualitatif, analisis data lebih difokuskan selama proses di lapangan bersamaan dengan pengumpulan data (Sugiyono, 2013: 240).

Pada penelitian ini, penulis akan melakukan tahapan-tahapan dalam menganalisis data kualitatif yaitu:

a. Raw data management (cleaning) yaitu tahapan analisis memisahkan data yang tidak relevan dengan fokus penelitian.

b. Data reduction terdiri dari: membagibagi (chunking), dan pelabelan (coding).

c. Data interpretation terdiri dari: pelabelan (coding), dan mengkategorikan (clustering); yaitu tahapan analisis mengenai penafsiran data dan pembahasan tentang struktur dan perubahan fungsi pertunjukan wayang golek purwa pada pesta syukur laut di pantai Pamayangsari Cipatujah.

d. Data representation terdiri dari: telling the story, making sense of the data for others. Yaitu tahapan analisis data dengan menarasikan hasil penafsiran dan pembahasan melalui tulisan.

\section{Teknik Penyajian Data}

Setelah data dianalisis, maka selanjutnya adalah menyajikan atau display data. Dalam penelitian kualitatif, penyajian data bisa dilakukan dalam bentuk uraian singkat, bagan, hubungan antar kategori dan sejenisnya.Dalam penelitian ini penulis akan menyajikan data berupa narasi-narasi data yang kemudian dituangkan dalam bentuk laporan.

\section{HASILDAN PEMBAHASAN}

\section{A. Sekilas Kesejarahan Wayang Masuk ke Tatar Sunda}

Sebelum membahas tentang awal mula pertunjukan wayang dijadikan media pesta syukur laut, terlebih dahulu akan dipaparkan ihwal kesejarahan wayang masuk ke bumi Parahyangan Sunda. Menurut berbagai sumber yang menjelaskan asal usul adanya pertunjukan wayang di bumi nusantara, bahwa wayang sudah dikenal sejak zaman animisme-dinamisme sebagai sarana upacara persembahan kepada roh para leluhur.

Pada saat itu masyarakat meyakini rohroh nenek moyang yang dulunya berkuasa masih memiliki kekuatan untuk diminta pertolongan melalui ritual tertentu. Hal tersebut mereka lakukan sebagai upaya untuk menghindari hal-hal yang buruk dan hal-hal yang tidak diinginkan terjadi. Maka, masyarakat melakukan upacara atau ritual pemujaan dan meminta pertolongan terhadap yang diyakininya itu. Pada masa itu, para pendahulu kita telah membuat alat-alat pemujaan berupa arca sebagai media untuk memanggil roh-roh atau arwah nenek moyang yang dinamakan Hyang (Marsaid, 2016: 60).

Untuk mengerti keinginan dari Hyang ini, maka diperlukan seorang mediator yang disebut Syaman. Hyang dan Syaman inilah yang merupakan asal mula pertunjukan wayang. Hyang menjadi wayang dan Syaman menjadi dalang serta ritual pemujaannya menjadi jalannya pentas/proses pementasan (Masroer, 2015: 25).

Seiring dengan sejarah perkembangan peradaban manusia dari masa ke masa, maka kesenian wayang pun terus berkembang mengikuti zaman sejalan dengan periodisasinya. Dimulai dari wayang di masa prasejarah, wayang zaman sejarah, wayang zaman Hindu, wayang zaman Islam, wayang zaman kemerdekaan, dan wayang pada saat ini (era teknologi informatika). Begitu panjang sejarah perkembangan wayang hidup berdampingan dengan 
Fipih, Cahya, Neneng - Perubahan Fungsi Pertunjukan.....

zamannya, wayang hingga kini masih digemari dan dihormati sebagai seni yang adiluhung ${ }^{1}$.

Pada akhirnya sampailah kepada ihwal kesejarahan seni pertunjukan wayang masuk ke bumi Parahyangan Sunda. Berdasarkan kajian literatur dan beberapa pendapat yang berhasil penulis kumpulkan, sejarah masuknya kesenian wayang ke tataran bumi Pasundan berawal dari peran aktif para bupati Priangan yang memiliki kepedulian terhadap kesenian, termasuk seni pedalangan yang mendapat tempat untuk diperkenalkan di kalangan menak pada saat itu (Hedy, 2011: 155).

Pertama, pada masa pemerintahan Rd. Aria Adipati Wiranatakusumah II (Bupati Bandung 1794-1829 M) yang bergelar Dalem Kaum. Pada saat itu Dalem Wiranatakusumah II berupaya untuk mengundang seorang dalang wayang kulit dari Tegal (Jawa Tengah) yaitu Ki Dipa Gunapermana, untuk memperkenalkan seni wayang di lingkungan tatar Sunda yang dimulai dari lingkungan keluarga menak sebagai tahap awal. Sebagai penghargaan dari Bupati Wiranatakusumah II terhadap dalang Dipa Guna Permana itu, maka diberilah sebuah gelar yaitu Dalang Lebet (Suanda, 1993: 1-15).

Upaya dan prakarsa yang sama juga dilakukan oleh Bupati Purwakarta pada masa pemerintahan Rd. Indra Diredja, dimana pada saat itu beliau memanggil dalang Ki Gubyar dan Ki Klungsu, keduanya berasal dari Tegal. Kedua dalang tersebut diberi tugas untuk mengajarkan ilmu pedalangan di wilayah Purwakarta, dengan cara dikumpulkannya sekelompok orang termasuk para abdi dalem terutama orang-orang yang memiliki hasrat untuk belajar kesenian khususnya seni pedalangan (Hedy, 2011: 157).

Periode selanjutnya adalah pada masa pemerintahan Rd. Aria Adipati Wiranatakusumah III (Bupati Bandung 1829-1846 M) yang bergelar Dalem Karang Anyar. Dalem Wiranatakusumah III berupaya untuk melanjutkan program pengembangan seni pedalangan di wilayah Bandung dengan cara mendatangkan dalang dari Jawa Tengah. Pada saat itu dalang yang diundang adalah Ki Rumyang, Ki Darman dan Ki Sura Sungging. Ki dalang Rumyang adalah murid Ki dalang Dipa Guna Permana dan mendapat gelar Dalang Sawat (Hedy, 2011: 158).

Memasuki zaman pemerintahan $\mathrm{Rd}$. Aria Adipati Wiranatakusumah IV (Bupati Bandung 1846-1874 M) yang bergelar Dalem Bintang. Keberadaan seni wayang golek di wilayah Bandung terus digalakkan dan semakin digemari oleh masyarakat luas sebagai hiburan rakyat yang menjadi daya tarik selera masyarakat pada saat itu (Hedy, 2011: 159).

Pada perkembangan berikutnya, setelah $\mathrm{Ki}$ Brajanata dikenal sebagai seorang dalang yang sudah populer sebagai murid dalang (catrik) terbaik dari Ki dalang Mama Anting (1885 M), maka masyarakat mendatangi Ki Brajanata untuk menjadi murid-murid dalang yang kelak sebagai generasi penerusnya. Murid-murid inilah yang mengemban tugas memperkenalkan kesenian wayang ke berbagai daerah di tataran sunda. Pada akhirnya seni pertunjukan wayang hidup dan berkembang seiring dengan zamannya, tetap membahana di bumi tatar Parahyangan Sunda hingga kini (Hedy, 2011: 160).

\section{B. Awal Mula Wayang Golek Purwa dijadikan Media Pesta Syukur Laut}

Setelah tersebarnya dan dikenalnya wayang di tataran Sunda, maka seiring dengan berjalannya waktu pada tahun 1975 kesenian wayang untuk pertama kali dipertontonkan dan diperkenalkan kepada masyarakat Pamayangsari. Pertunjukan wayang golek purwa merupakan hiburan terakhir sekaligus penutup dari seluruh rangkaian kegiatan pesta syukur laut yang dipentaskan setelah upacara adat yaitu larung jempana ke tengah laut.

\footnotetext{
${ }^{1}$ Adiluhung adalah ungkapan untuk karya-karya masa lalu yang berarti mulia dan utama.
} 


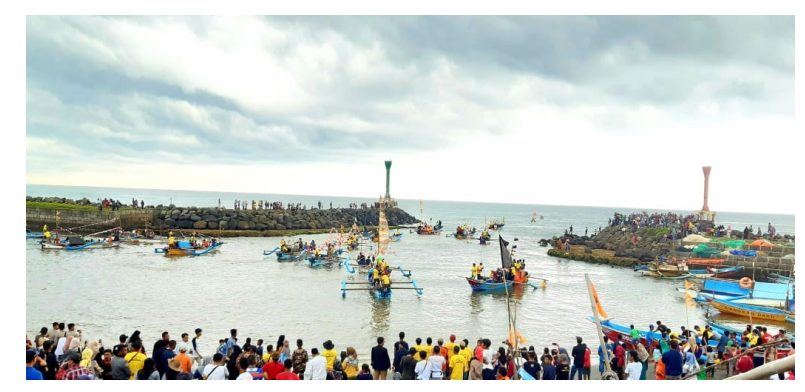

Gambar 1. Larung Jempana.

(Foto: Dok. Fipih Fauziah, 28 Desember 2019)

Para sesepuh/tokoh adat yang dipandang cukup berpengaruh di mata masyarakat, telah memilih seni pertunjukan wayang golek purwa sebagai bagian dari sarana pesta syukur laut, karena wayang golek purwa merupakan budaya buhun.Pada seni pertunjukan wayang golek terdapat banyak misi yang terkandung di dalamnya antara lain, simbol-simbol kehidupan, spiritual, silaturahmi, edukasi nilai, dan sebagai sarana hiburan yang paling dominan di masyarakat.

Bentuk pertunjukan wayang golek pada pesta syukur laut tentunya agak berbeda dengan format pertunjukan wayang golek murni sebagai hiburan. Dalam posisinya sebagai media ritual pesta syukur laut, maka di dalamnya dapat dijumpai hal-hal yang bersifat sakral religius seperti hadirnya sesaji, aneka makanan umbi-umbian, kepala kerbau, kain putih, dan lainnya.

Hal lain yang mencirikan suasana dan kondisi sakral religius pada pertunjukan wayang golek syukur laut, adalah jenis cerita atau lakon wayang yang disesuaikan dengan tema utama upacara ruwatan yaitu lakon Batara Kala. Lakon Batara Kala adalah sebuah cerita galur atau cerita pokok yang sudah baku khusus disajikan sebagai lakon untuk ruwatan. Lakon Batara Kala pada pertunjukan wayang sebagai media ruwatan menggambarkan kisah kehidupan tokoh Batara Kala seorang Dewa dari kahyangan dengan segala kesaktiannya, sengaja turun ke bumi untuk mencari mangsa manusia yang dijadikan tumbal atau dikorbankan.

Adapun pertunjukan wayang golek purwa yang dikhususkan untuk ritual ruwatan itu berbeda dengan pertunjukan/pementasan wayang golek purwa pada umumnya. Berdasarkan pemaparan bapak dalang Oza K. Sunarya (36 tahun), perbedaan tersebut di antaranya:

1. Ruwatan itu bersifat sakral

Ruwatan bersifat sakral karena merupakan sebuah tradisi kepercayaan yang berawal dari ajaran nenek moyang yaitu animisme dan dinamisme, selanjutnya dipengaruhi oleh ajaran Hindu, serta dipengaruhi oleh ajaran Islam.

Menurut bapak dalang Oza K. Sunarya (36 tahun) dalam hal ngaruwat, pada praktiknya terdapat dua jenis ruwatan, yaitu:

a. Ruwatan pokok yaitu menetralisir keselamatan masyarakat sagma alam, adanya ruwatan itu mempersatukan alam, daerah sama masyarakatnya dan kita menghormati orang-orang sebelum kita. Contohnya ruwatan syukur laut, ruwatan hajat gedung, dan ruwatan perusahaan.

b. Ruwatan lembur atau tempat yaitu ruwatan untuk menetralisir tempat saja, contohnya ruwatan rumah.

2. Cerita yang dibawakandalam ruwatan pokok harus menceritakan kisah atau lakon Batara Kala, sedangkan ruwatan lembur hanya cerita atau lakon biasa.Berikut ini kisah atau lakon singkat dari Batara Kala menurut penuturan bapak dalang Oza $\mathrm{K}$. Sunarya (36 Tahun):

Batara Kala teh sajenis raksasa, kabeukina teh ngadaharan daging atah, ku Batara Guru ditempatkeun di hutan jauh ti manusa supaya manusa aman, kadaharana teh sasatoan heg sok didahar atah, kadieunakeun si Batara Kala hayang ngaraosan getih manusa, teras akhirna ngaraosan getih manusa, ternyata lewih enak getih manusa dibanding darah atau daging hewan, kusabab ngeunah kadieunakeun si Batara Kala boga 
Fipih, Cahya, Neneng - Perubahan Fungsi Pertunjukan.....

kahayang rek ngahakanan atawa rek mencitan jelema. Nya ngadu ka Batara Guru atawa ka Hyang Natipati Jagat

Natahya atawa nu disebut Tuhan di zaman harita, cek Batara Kala: "geuningan ngeunah keneh daging manusia dibanding daging hewan, naha teu ngabejaan ka kuring" dijawab ku Batara Guru:"pek wae meunang di dahar kumaneh daging manusa, asal teu menang make bedog, jeung teu meunang make leungeun bisi keuna ku sifata atawa pamali" (ceuk dina salah sahiji pasal-pasal buku wawacan Batara Kala).

3. Dalam hal sesaji, setiap pertunjukan wayang merupakan suatu keharusan, baik wayang tradisi maupun wayang hiburan. Berdasarkan pemaparan bapak Aang (74 tahun) selaku sesepuh/tokoh adat masyarakat nelayan Pamayangsari, bahwa nenek moyang dahulu dalam menggelar syukur laut pada seluruh rangkaian acaranya memiliki nilai sakral baik itu ungkapan terima kasih dengan media larung maupun harapan agar terhindar dari mara bahaya dengan media ruwatan. Kedua ritual tersebut harus diisi dengan sesaji yang lengkap.

4. Waktu pelaksanaan ritual ruwatan, waktu yang dibutuhkan dalam pagelaran disaat ngaruat dari jam 12 malam sampai dengan jam 3 subuh.

5. Gamelan iringan atau Tatabeuhan, dalam hal ini, gamelan atau musik pengiring yang dibawakan adalah gamelan wayang tradisi (gamelan konvensional), yang berbeda dengan gamelan wayang kontemporer.

6. Waktu pertunjukan: Kalau wayang khusus tradisi ruwatan waktu pertunjukannya itu semalam suntuk dan munel (berbarengan tanpa henti), ngaruat harus dilakukan pada malam hari, dimulai setelah azan magrib selesai hingga waktu subuh.

7. Cara membawakan wayang: wayang golek purwa tradisi ruwatan itu baik dalang maupun penonton harus dilaksanakan dengan lebih hikmat dan harus disaksikan sampai selesainya pertunjukan. Sedangkan wayang golek kontemporer, cara membawakannya lebih santai, unsur hiburannya lebih banyak dibanding cerita yang dibawakan. Setelah tahun 1987 masyarakat nelayan Pamayangsari mengalami penurunan dari segi pendapatan harian, sehingga tidak mampu menyelenggarakan wayang ruwatan. Tapi sebagian besar masyarakat nelayan masih menginginkan dan menghormati budaya peninggalan nenek moyang, maka pertunjukan wayang golek purwa tetap dilaksanakan tanpa ruwatan sebagai gantinya masyarakat nelayan Pamayangsari menyertakan unsur sesaji di dalamnya. Seiring berjalannya waktu, pada tahun 2006 terjadi pro kontra di masyarakat mengenai unsur sesaji dalam pesta syukur laut.

\section{Kelengkapan Sarana Pesta Syukur Laut di Pantai Pamayangsari}

Dalam pesta syukur laut nelayan terdapat upacara adat/ritual yang dilaksanakan sebagai inti dari seluruh rangkaian kegiatan syukur laut nelayan yaitu pelarungan jempana ke tengah laut. Demi terlaksananya pelaksanaan upacara tersebut, maka harus didukung dengan kelengkapan sarana yang memadai.

Berdasarkan hasil wawancara dengan bapak Sana Sopiana (38 tahun) selaku ketua Rukun Nelayan Pamayangsari, mengenai upacara adat/ritual pelarungan jempana ke tengah laut dari dulu sampai sekarang memang selalu dipimpin oleh sesepuh/tokoh adat. Berikut sesepuh/tokoh adat yang telah memimpin jalannya ritual tersebut dan diteruskan secara turun temurun yaitu dimulai oleh alm. Ulung Sujana (1975-1983 M), alm. Aki Ukri (1983- 
1985 M), alm. Abah Kancil (1985-1987 M), alm. Abah Tanu (1987-1989 M), dan bapak Aang (1993 M s.d. sekarang).

Menurut penuturan bapak Aang (74 tahun) selaku sesepuh/tokoh adat masyarakat nelayan Pamayangsari, demi suksesnya penyelenggaraan syukur laut memang harus direncanakan dan dipersiapkan dengan baik termasuk mengenai acara inti yaitu larung jempana ke tengah laut. Dari mulai penentuan puseran (tanda) di tengah laut, kemudian menyiapkan jempana, serta terakhir menyiapkan isian jempana (sesaji). Berikut uraian/penjelasan kelengkapan sarana pesta syukur laut:

1. Penentuan puseran (tanda) di tengah laut.

2. Menyiapkan jempana. Jempana adalah tandu/usungan berbentuk replika rumah dengan ukuran panjang 1,2 meter, ukuran lebar 0,6 meter, dan ukuran tinggi 2 meter. Berdasarkan penuturan bapak Sana Sopiana (38 tahun) bahwa bentuk jempana yang dibuat terdiri dari bangunan dasar berbentuk persegi dan atap pertama berbentuk prisma, diatasnya lagi terdapat atap kedua dan ketiga berbentuk prisma lebih kecil dari atap pertama, dan atap ke empat terdapat bangunan seperti mercusuar dan di bagian akhir terdapat atap berbentuk prisma segi empat terbalik, menyerupai gaya bangunan/arsitektur dari sebuah surau/ masjid.

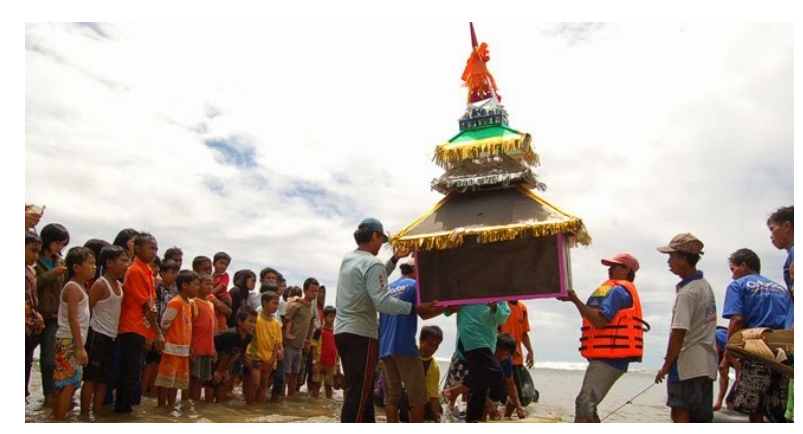

Gambar 2. Persiapan pengangkatan Jempana sebelum dilarungkan.

(Foto: Dok. Fipih Fauziah, 28 Desember 2019)
Masih menurut bapak Sana Sopiana (38 tahun), makna yang terkandung dari bentuk bangunan jempana tersebut yaitu bahwa upacara adat/larung jempana adalah proses dari sebuah akulturasi budaya, antara budaya lokal sama budaya Islam bisa selaras dan sejalan, serta jika dihitung jumlah bangunan penyusun jempana terdiri dari lima buah. Adapun makna yang terkandung di dalamnya, yaitu mengenai pegangan hidup bangsa Indonesia yaitu pandawa lima, Pancasila dan rukun Islam.

Sedangkan untuk makna dari warna-warna yang dikombinasikan dalam jempana tersebut tidak jauh berbeda dengan makna warna pada umumnya. Warna garis pinggir bangunan dasar berwarna merah muda makna yang terkandung yaitu cinta dan kasih sayang artinya sesama nelayan itu harus saling menyayangi satu sama lain. Warna garis pinggir atap pertama dan ketiga berwarna kuning, makna yang terkandung di dalamnya yaitu muda, gembira dan ceria, artinya dalam menjalankan profesi sebagai nelayan harus berjiwa muda (optimisme), harus memiliki kebanggaan terhadap profesi nelayan. Warna dinding bangunan dasar dan atap yang pertama dan atap yang kedua berwarna cokelat, makna yang terkandung dari cokelat adalah stabil, kokoh dan bisa diandalkan artinya profesi nelayan ini diharapkan jadi penggerak ekonomi masyarakat nelayan. Warna atap yang ketiga berwarna hijau, makna yang terkandung dari hijau adalah kesejukan, kesehatan dan keberuntungan artinya dalam menjalankan profesi nelayan ini diharapkan masyarakatnya diberi kesejukan (saling membantu dan tidak saling menjatuhkan), dalam melaut selalu diberi kesehatan, dan selalu diberi keberuntungan berupa hasil laut yang melimpah. Warna atap yang keempat berwarna biru sensitif, kesetiaan dan ketenangan artinya masyarakat nelayan harus 
Fipih, Cahya, Neneng - Perubahan Fungsi Pertunjukan.....

sensitif dalam artian baik yaitu meningkatkan kewaspadaan dengan membaca tanda-tanda yang ada di laut, masyarakat nelayan harus setia terhadap apa yang menjadi keyakinannya yaitu agama Islam, serta ketenangan yaitu dalam menjalani profesi nelayan harus tenang dalam mengambil keputusan dan tidak boleh tergesagesa. Atap yang terakhir berwarna merah, makna yang terkandung yaitu semangat, percaya diri, kuat dan berani, artinya setiap nelayan itu harus memiliki jiwa semangat, percaya diri terhadap kemampuan diri sendiri (tidak bergantung kepada orang lain), kuat dalam menghadapi arus laut dan seorang nelayan itu harus berani menegakkan kebenaran.

3. Menyiapkan isian jempana. Sesaji yang terdapat di upacara adat/ritual syukur laut nelayan Pamayangsari merupakan jenis sesaji selametan atau bentuk ucapan syukur kepada Tuhan Yang Maha Esa atas anugerah yang diberikan berupa hasil/ tangkapan ikan laut yang melimpah serta memohon perlindungan dari berbagai bencana alam.

4. Adapun isian sesaji yang disiapkan sesepuh dahulu dalam upacara adat/ritual syukur laut nelayan di pantai Pamayangsari dari tahun 1975 s.d. 2005 yaitu terdiri dari: rurujakan $40 \mathrm{rupa} / \mathrm{jenis,} \mathrm{kupat} \mathrm{tujuh} \mathrm{rupa/}$ jenis, bunga tujuh rupa/warna, kelapa muda, dupa, bekakak ayam, kepala hewan ternak atau sapi, kepala munding bule/ kerbau atau kepala kambing hitam yang dibungkus dengan kain putih. Sedangkan dari 2006 s.d. sekarang isian sesaji yang biasa disiapkan sesepuh dahulu dihilangkan, karena bertentangan dengan syariat agama Islam.

\section{Keberadaan Tradisi Pertunjukan Wayang Golek Purwa Pasca Tsunami Cipatujah 2006 di Pantai Pamayangsari Desa Cikawungading} Pada tahun 2006 telah terjadi sebuah bencana alam yaitu tsunami di sepanjang pantai selatan pulau Jawa seperti dilansir elshinta.com:

Senin tanggal 17 Juli 2006 pukul 15:19 WIB, terjadi gempa berkekuatan M7.7 dengan pusat gempa di lepas pantai Pangandaran. Gempa dengan kekuatan sebesar itu termasuk moderate, biasanya tidak menimbulkan tsunami. Akan tetapi gempa Pangandaran menimbulkan tsunami dengan ketinggian lebih dari $5 \mathrm{~m}$ dan rayapan mencapai $21 \mathrm{~m}$. Gempa merenggut 668 korban jiwa, 65 hilang (diasumsikan meninggal dunia) dan 9.299 lainnya luka-luka. Tsunami itu menghantam desa-desa di pesisir selatan Jawa di Cipatujah, Tasikmalaya dan di Pangandaran, Ciamis.

Berdasarkan wawancara dengan bapak Iwan Nasihin (33 tahun) selaku perangkat/pegawai Desa Cikawungading, mengenai daerah yang terkena bencana tsunami pada tahun 2006, terdapat dua desa di Kecamatan Cipatujah yang terkena bencana tsunami yaitu pantai Ciheras dan pantai Cipatujah, di Kecamatan Cikalong ada satu desa yaitu pantai Cimanuk. Sedangkan menurut bapak Sana Sopiana (38 tahun) selaku ketua Rukun Nelayan Pamayangsari menyatakan bahwa pantai Pamayangsari pada tahun 2006 bukan merupakan daerah yang terkena tsunami.

Kejadian bencana alam tsunami tidak hanya merusak tatanan habitat alam tetapi meninggalkan rasa trauma yang sangat bagi kondisi kejiwaan masyarakat yang tinggal di dekat pantai, terutama masyarakat yang secara langsung merasakan datangnya tsunami diantaranya masyarakat nelayan Ciheras, masyarakat nelayan 
Cipatujah, dan masyarakat nelayan Cimanuk. Meskipun pantai Pamayangsari bukan merupakan daerah yang terkena tsunami, tapi masyarakat nelayan Pamayangsari merasakan hal yang sama dengan apa yang dirasakan masyarakat nelayan sekitarnya yaitu kondisi ketakutan akan adanya tsunami susulan.

Pesta syukur laut nelayan tidak hanya dilaksanakan di pantai Pamayangsari saja, tetapi dilaksanakan juga di pantai Cimanuk, karena pesta syukur laut merupakan tradisi turun temurun yang diwariskan dari nenek moyang para nelayan terdahulu. Pada tahun 1975 nenek moyang para nelayan sudah membentuk satu kesatuan masyarakat adat yang dinamakan Rukun Nelayan yang keanggotaannya terdiri dari 7 Desa yang memiliki wilayah topografi/permukaan bumi berupa kawasan pantai, yaitu Desa Ciheras, Desa Cipatujah, Desa Sindangkerta, Desa Cikawungading, Desa Cidadap, Desa Mandalajaya, dan Desa Cimanuk.

Untuk Desa Ciheras, Desa Cipatujah, Desa Sindangkerta, Desa Cikawungading, dan Desa Cidadap pelaksanaan pesta syukur laut dilaksanakan di pantai Pamayangsari. Sedangkan untuk Desa Mandalajaya dan Desa Cimanuk pelaksanaan pesta syukur laut dilaksanakan di pantai Cimanuk.

Tujuan dan fungsi diadakannya pesta syukur laut nelayan yang didalamnya terdapat ritual ruwat dan ritual larung, salah satu tujuannya adalah menolak bala bencana dan mara bahaya, serta supaya diberi hasil/tangkapan ikan laut yang melimpah.Tapi, pada kenyataannya pesta syukur laut nelayan tersebut oleh sebagian besar masyarakat nelayan dianggap hal yang sia-sia, karena tidak bisa menolak atau membatalkan datangnya tsunami. Sehingga oleh sebagian besar masyarakat nelayan Pamayangsari yang meyakini fungsi ruwatan sebagai penolak bala berubah menjadi tidak meyakini fungsi ruwatan tersebut. Oleh karena itu, maka ritual ruwatan tidak lagi dipakai oleh masyarakat dikarenakan masyarakat menganggap dengan adanya atau tidak adanya ritual ruwatan kondisinya sama saja atau tidak memberikan perubahan apa pun bagi keberlangsungan hidup masyarakat nelayan Pamayangsari.

\section{E. Struktur Pertunjukan Wayang Golek Purwa pada Pesta Syukur Laut di Pamayangsari}

Berdasarkan hasil observasi penulis dan dari berbagai sumber yang relevan mengenai struktur pertunjukan wayang golek purwa pada pesta syukur laut masyarakat nelayan Pamayangsari Desa Cikawungading Kecamatan Cipatujah Kabupaten Tasikmalaya terdiri dari tiga tahapan, yaitu: pertama tahapan pra-pertunjukan atau persiapan, kedua tahapan pementasan/ pertunjukan, dan ketiga tahapan penutupan.

\section{F. Pra-pertunjukan/Persiapan Wayang Golek Purwa}

Pada tahapan ini kegiatan dimulai dengan membacakan doauntuk kelancaran pertunjukan wayang golek purwa yang dipimpin oleh ketua panitia syukur laut nelayan Pamayangsari, yaitu bapak Sana Sopiana. Selanjutnya, seluruh anggota sanggar seni MPP dibantu oleh panitia penyelenggara pesta syukur laut nelayan Pamayangsari mempersiapkan sarana dan prasarana, pelaku pertunjukan dan sambutan-sambutan:

\section{Sarana dan Prasarana}

Menurut penuturan bapak dalang Wawan Dede Amung S (47 tahun) selaku ketua sanggar seni MPP menjelaskan bahwa sarana pertunjukan wayang golek purwa yang dimiliki sanggar seni MPP sudah sangat lengkap, kelengkapan sarana 
tersebut terdiri dari: Satu Set Boneka Wayang; Satu Set Gamelan; Gedebog; Tapak Dara; Jagat Nagaraja; Janturan; Gugunungan; Kecrek Wayang; Cempala; Kotak Wayang; dan Pandel.

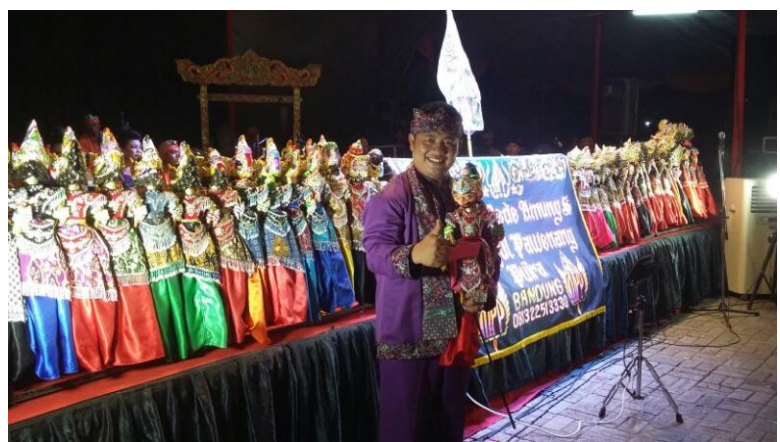

Gambar 3. Bapak dalang Wawan Dede Amung S sedang memangku boneka wayang golek purwa. (Foto: Dok. Wawan Dede Amung S, 6 Mei 2020)

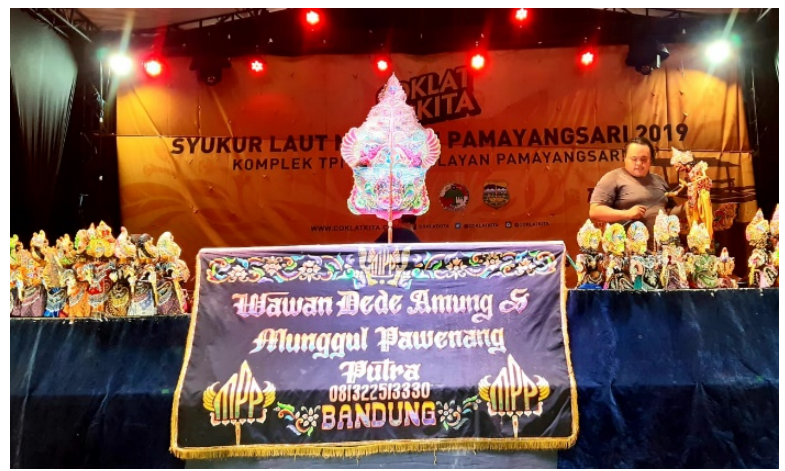

Gambar 4. Identitas rombongan sanggar seni MPP yang tertera pada pandel.

(Foto: Dok. Fipih Fauziah, 28 Desember 2019)

2. Pelaku Pertunjukan Wayang Golek

Tahapan yang kedua, yaitu mempersiapkan para pelaku/orang yang ikut berperan penting dalam pertunjukan wayang golek purwa. Di antaranya adalah dalang, grup pangrawit, dan panitia penyelenggara.

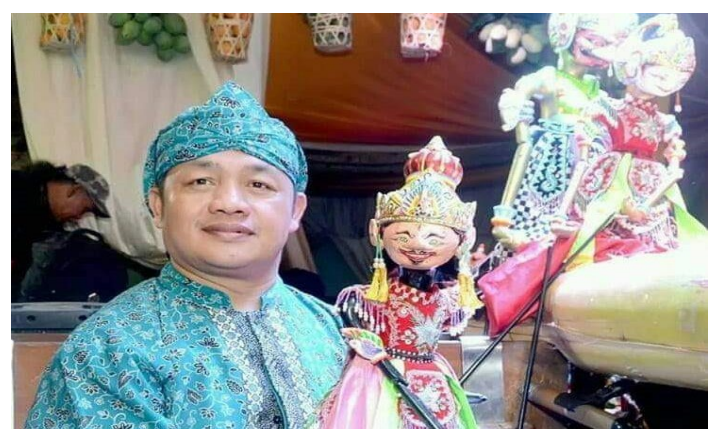

Gambar 5. Bapak dalang Wawan Dede Amung S. (Foto: Dok. Wawan Dede Amung S, 6 Mei 2020)

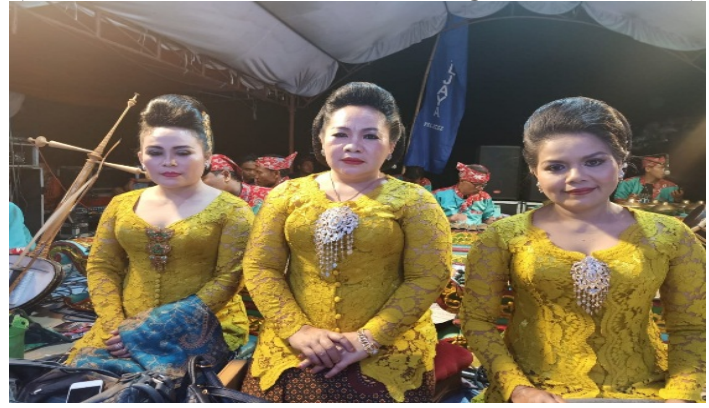

Gambar 6. Sinden sanggar seni MPP.

(Foto: Dok. Wawan Dede Amung S, 6 Mei 2020)

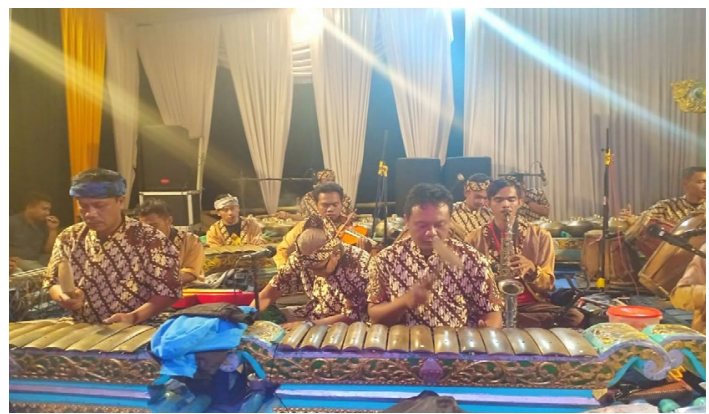

Gambar 7. Panayagan sanggar seni MPP. (Foto: Dok. Wawan Dede Amung S, 6 Mei 2020)

\section{Sambutan Para Tamu Undangan}

Tahapan ketiga dari pra-pertunjukan/persiapan wayang golek purwa adalah sambutan-sambutan dari para tokoh masyarakat Pamayangsari. yaitu: bapak Sana Sopiana selaku ketua panitia pesta syukur laut, bapak Mustarom selaku kepala Desa Cikawungading, bapak Kostaman selaku unsur Muspika (Musyawarah Pimpinan Kecamatan) Cipatujah. 


\section{G. Pementasan/Pertunjukan Wayang Golek Purwa}

Setelah sambutan-sambutan/biantara dari panitia dan tamu undangan selesai, tahapan selanjutnya adalah pementasan/pertunjukan wayang golek purwa. Berdasarkan observasi penulis di lapangan pada tanggal 28 Desember 2019 dan hasil wawancara dengan bapak dalang Wawan Dede Amung S (47 tahun), secara umum pementasan pertunjukan wayang golek purwa dibagi dalam tiga babak, yaitu babak pertama/pembukaan, babak kedua/pertunjukan, dan babak ketiga/penutupan.

Babak pertama ditandai dengan instrumen (tatalu) yang diperagakan grup pangrawit, kemudian dalang dan sinden naik panggung. Setelah itu, juru alok (wirasuara) membuka pertunjukan wayang dengan memperkenalkan profil rombongan, selanjutnya juru alok (wirasuara) mempersilahkan sinden menyanyikan lagu Kembang Gadung, berikut lirik dari lagu Kembang Gadung:

Judul lagu: Kembang Gadung

Bismillah bubuka lagu

muji sukur ka Hyang Agung

sumembah ka sang karuhun

sumujud ka Batara Agung

neda widi neda amit

ka Gusti Nu Maha Suci

mugi diaping dijaring

neda pangraksa pangriksa

sareng ka para karuhun

nyanggakeun ieu pangbakti duh

Gusti

ulah bade hiri dengki

duh alah...

kembang gadung nu kahatur

nyanggakeun ieu pangbakti

pangbakti ti seuweu-siwi

Bapak dalang Wawan Dede Amung S mencabut gugunungan sebagai pertanda pertunjukan wayang memasuki babak pertama/pembukaan cerita pewayangan. Cerita pewayangan mengisahkan lakon wayang sesuai dengan judul yang diminta oleh panitia penyelenggara, lakonlakon atau cerita yang akan dibawakan biasanya cerita-cerita karya ciptaan atau karangan dari dalang itu sendiri berdasarkan kehidupan sehari-hari atau cerita rakyat Jawa Barat yaitu cerita carangan (Humas Pemprov. Jawa Barat, 2018: 16).

Selanjutnya bapak dalang Wawan Dede Amung memulai jejer (adegan) pertama dengan memperagakan ibing-ibingan tari maktal. Setelah itu, dilanjutkan jejer (adegan) kedua yaitu dialog para pejabat Kerajaan Amarta yaitu Batara Guru sebagai raja, Batara Rama sebagai patih, Batara Kresna sebagai penasihat raja, dan Arjuna sebagai panglima perang. Topik yang dibicarakan adalah seputar aturan-aturan yang berlaku di kerajaan tersebut.

Setelah itu, jejer (adegan) ketiga yaitu kemunculan lakon utama yaitu si Cepot yang mendatangi Kerajaan Amarta untuk menyampaikan unek-unek yang sudah membuatnya gelisah belakangan ini. Selanjutnya, si Dawala datang sambil bernyanyi lagu "Tongtolang Nangka". Setelah itu bapak dalang Wawan Dede Amung S mengajak grup pangrawit untuk ikut bernyanyi bersama menyanyikan lagu tersebut.

Dalam adegan tersebut si Cepot menjelaskan maksud dan tujuan kedatangannya bersama si Dawala ke Kerajaan Amarta, yaitu mengenai ayahnya Semar yang bersumpah di hadapannya. Isi sumpah tersebut yaitu bahwa Semar merupakan titisan Dewa dari sewarga yang terkenal sebagai orang kaya dan sengaja meninggalkan warisan harta kekayaan di sewarga untuk si Cepot dan si Dawala. Dalam perjalanan spiritualnya Dewa tersebut berubah wujud menjadi seorang Semar. Selanjutnya, si Cepot meminta ijin kepada Batara Guru selaku raja Amarta 
Fipih, Cahya, Neneng - Perubahan Fungsi Pertunjukan.....

untuk pergi ke sewarga mengambil sisa warisan dari ayahanda Semar. Tetapi, atas saran Batara Rama, Batara Guru menolak memberi ijin kepada si Cepot.

Selanjutnya, setelah si Cepot menyampaikan unek-unek mengenai dugaan bahwa ayahnya Semar meninggalkan warisan kekayaan di sewarga. Arjuna dan Batara Rama tidak bisa menerima bualan si Cepot dan malah menganggap si Cepot dan si Dawala punya niat lain, terjadilah jejer (adegan) keempat yaitu perkelahian yang luar biasa hebat antara si Cepot, si Dawala, dengan Batara Rama, dan Arjuna. Dari perkelahian tersebut belum terlihat siapa yang lebih unggul satu sama lain. Akhirnya si Cepot dan si Dawala memilih pergi dan berhasil kabur meninggalkan istana Kerajaan Amarta, tetapi dengan penuh rasa kecewa terhadap anggota keluarga kerajaan yang terkenal harum semerbak akan kebijaksanaannya.

Di sisi lain, sang raja Batara Guru masih terlihat kebingungan dan penasaran akan cerita yang diucapkan si Cepot. Batara guru seolah-olah merasa bersalah tidak memberi izin kepada si Cepot dan si Dawala untuk pergi ke Sewarga. Berbeda dengan Batara Guru, Batara Rama merasa dipermalukan dengan sikap si Cepot dan si Dawala. Kemudian, Batara Rama memanggil raden Gatot Kaca untuk menangani ulah pembangkangan si Cepot dan si Dawala, serta dengan segera menyusun rencana untuk menemukan dan menangkap si Cepot serta si Dawala.

Setelah itu, bapak dalang Wawan Dede Amung S menancapkan gugunungan sebagai tanda berakhirnya babak cerita pembukaan, dan sebagai tanda bergantinya babak baru atau latar baru. Jejer (adegan) pertama dari babak kedua, yaitu seorang komandan sedang melatih dan mengetes bawahannya, dia ditugaskan oleh Gatot Kaca untuk mencari dan menangkap si Cepot Sastrajingga dan si Dawala.
Selanjutnya, jejer (adegan) kedua, yaitu perkelahian antara si Cepot dengan Komandan pasukan Kerajaan Amarta. Dalam hal ini, bapak dalang Wawan Dede Amung $\mathrm{S}$ sangat mengetahui seluk beluk gerakan silat, terbukti dengan begitu menariknya pertunjukan silat antara wayang si Cepot dengan wayang komandan pasukan Kerajaan Amarta.

Selanjutnya, jejer (adegan) ketiga, yaitu perkelahian antara si Dawala dengan para prajurit Kerajaan Amarta. Si Dawala berhasil mengalahkan satu persatu prajurit Kerajaan Amarta. Pada adegan tersebut prajurit dibuat tidak berkutik sampai keluar kata-kata menyerah "ampun ksatria Dawala" dari mulut para prajurit Kerajaan Amarta. Setelah adegan perkelahian silat tersebut, selanjutnya bapak dalang Wawan Dede Amung S melanjutkan jejer (adegan) dengan cerita tambahan wayang $\mathrm{H}$. Muhidin dengan wayang si Dawala.

Setelah adegan tambahan tersebut, bapak dalang Wawan Dede Amung S menancapkan kembali gugunungan sebagai pertanda berakhirnya babak kedua. Selanjutnya, cerita pertunjukan wayang akan memasuki babak ketiga atau babak akhir. Selanjutnya, Ki dalang menarasikan cerita bahwa berita tentang tak ada satu pun prajurit dan bala tentara dari Kerajaan Amarta yang berhasil mengalahkan si Cepot Sastrajingga dan si Dawala sampai terdengar oleh raden Gatot Kaca.

Jejer (adegan) pertama dari babak ketiga/babak akhir yaitu si Cepot dan si Dawala dihampiri oleh raden Gatot Kaca. Pada adegan tersebut terjadi dialog antara raden Gatot Kaca dengan si Cepot, raden Gatot Kaca menyarankan agar si Cepot mengurungkan niatnya pergi ke sewarga. Raden Gatot kaca memberi peringatan kepada si Cepot dan si Dawala, jika tetap akan pergi ke sewarga maka akan berhadapan dengan kesaktian dan nama besar raden Gatot Kaca. Si Cepot hanya ingin 
membuktikan sumpah dari ayahnya yaitu Semar. Semar bersumpah bahwa dia sudah menyisakan warisan kekayaannya di sewarga. Akhirnya si Cepot harus berhadapan dengan raden Gatot Kaca, tetapi si Cepot lebih dulu menyuruh adiknya si Dawala untuk melayani tantangan raden Gatot Kaca.

Selanjutnya, dilanjutkan dengan jejer (adegan) kedua dari babak ketiga, yaitu perkelahian antara raden Gatot Kaca dengan si Dawala. Dalam perkelahian tersebut raden Gatot Kaca berhasil mengalahkan si Dawala, si Dawala masih belum setara dengan kesaktian raden Gatot Kaca. Akhirnya raden Gatot Kaca pergi meninggalkan si Dawala. Selanjutnya setelah raden Gatot Kaca pergi dilanjutkan jejer (adegan) ketiga yaitu si Cepot menghampiri si Dawala dan segera menghidupkan kembali si Dawala. Si Dawala sempat ragu bahwa kakaknya si Cepot mempunyai ilmu yang sangat sakti. Kemudian, si Dawala menyuruh si Cepot mematikan dan menghidupkan kembali dirinya. Lalu, si Cepot melakukannya. Kemudian, si Dawala pun percaya akan ilmu kesaktian yang dimiliki kakaknya, dan dengan percaya diri si Cepot berkata hanya si Cepot yang sanggup menghadapi raden Gatot Kaca.

Kemudian, pada jejer (adegan) keempat yaitu si Cepot dan si Dawala menghampiri raden Gatot Kaca. Terjadilah perkelahian yang tak terelakkan lagi, akan tetapi perkelahian antara si Cepot dengan raden Gatot Kaca tidak berlangsung lama, adegan perkelahian dimulai dengan serangan ilmu raden Gatot Kaca yang dilancarkan kepada si Cepot. Tetapi tidak menimbulkan efek apa pun pada si Cepot, kemudian si Cepot mengucap kata "paeh" dan raden Gatot Kaca pun mati seketika. Kemudian, si Cepot dihampiri adiknya yaitu si Dawala, terus adiknya meminta kepada si Cepot untuk menghidupkan kembali pahlawan raden Gatot Kaca. Si Dawala meyakinkan si Cepot bahwa raden Gatot Kaca hanya melaksanakan tugas dinas kenegaraan. Dalam hati seorang raden Gatot Kaca pasti mengingkari akan titah dari Batara Rama tersebut.

Jejer (adegan) kelima yaitu si Cepot menghidupkan kembali raden Gatot Kaca, raden Gatot Kaca pun akhirnya mengakui akan ilmu kesaktian yang dimiliki si Cepot. Sebagai balasan atas perbuatan baik si Cepot, raden Gatot Kaca memijat punggung si Cepot yang mulai bungkuk dan meminta untuk diangkat sebagai murid kepada si Cepot. Setelah perkelahian selesai, si Cepot menitip pesan kepada raden Gatot Kaca agar menyampaikan bahwa si Cepot akan tetap pergi ke sewarga dan menantang kepada siapa saja yang menghalangi akan si Cepot lawan meskipun Batara Rama, Arjuna, dan Batara Kresna, bila perlu tiga lawan satu.

Kemudian jejer (adegan) keenam atau terakhir dari babak ketiga cerita yang dipentaskan diisi dengan pidato kebudayaan si Cepot tentang pesan-pesan moral kepada para penonton khususnya para nelayan. Berikut penggalan isi pidato tersebut:

Ayo saya mengajak kepada semuanya orang sunda, peliharalah budaya kita, oleh siapa lagi dipelihara nya budaya bangsa kita jika bukan oleh bangsa sendiri. Adapun gelar "ki dalang", "ki" adalah "kiyai" memiliki arti sama dengan "kiyai ulama". Ingin menanyakan hal apa kepada dalang asalkan tentang wayang, sama dengan kiyai ulama, akan menanyakan hal apa kepada ulama asal kan tentang Agama. Oleh karena itu jangan asal diharamkan hanya karena dulu ada tradisi ruwatan. "ruwatan" adalah "bahasa buhun", "buhun" adalah "bahasa nenek moyang”, seperti bahasa "janga wareng”. Karena kita lahir/berasal dari 
Fipih, Cahya, Neneng - Perubahan Fungsi Pertunjukan.....

ibu, ibu dari nenek, nenek dari buyut, buyut dari "bao" (ibu buyut), bao dari udeg-udeg (ibu bao), udeg-udeg dari janga wareng (ibu udeg-udeg), janga wareng dari kait (ibu janga wareng), kait dari siwur (ibu kait), siwur dari babu hawa (ibu siwur). Semua uraian tadi disebut juga dengan istilah "para karuhun/nenek moyang". "Para" adalah di atas, "karuhun" adalah leluhur, jadi artinya leluhur kita yang sudah meninggal, kalau menurut anak sekolah disebutnya dengan istilah "nenek moyang". Istilahnya berterima kasih kepada para nelayan dan PT. Djarum Santosa yang selama ini tetap mementaskan hiburan wayang. Hal itu merupakan suatu kebanggaan dan penilaian yang luar biasa dari saya pribadi selaku dalang, karena tidak hanya di Pamayangsari, saya juga pernah tampil di Batukaras dan Pangandaran. Memberikan penghargaan setinggi-tingginya untuk para nelayan, disisi lain sebagai hiburan bagi masyarakat dan juga untuk melestarikan budaya nenek moyang kita yaitu wayang golek yang merupakan seni buhun yang penuh dengan falsafah, filosofi tentang kehidupan manusia sekarang.

Setelah pidato si Cepot berakhir, bapak dalang Wawan Dede Amung S menancapkan gugunungan sebagai tanda berakhirnya cerita/kisah/lakon dalam pertunjukan wayang golek purwa pada pesta syukur laut di Pamayangsari Cipatujah.

Jadi, dapat disimpulkan bahwa pementasan/pertunjukan wayang golek purwa pada pesta syukur laut di Pamayangsari diawali dengan lagu Kembang Gadung, selanjutnya dalang melakukan kakawen pada babak pembukaan, kakawen sebelum babak kedua berakhir, dan kakawen sebelum si Cepot pidato. Secara umum pertunjukan wayang golek purwa dibagi dalam tiga babak, akan tetapi yang membedakan antara satu pertunjukan dengan pertunjukan lainnya yaitu per jejer (adegan) cerita wayang. Pada pementasan di Pamayangsari terdiri dari 14 jejer (adegan), yaitu babak pertama/pembukaan terdiri dari satu jejer (adegan) tari, satu jejer (adegan) dialog, satu jejer (adegan) bodoran, dan satu jejer (adegan) perkelahian, babak kedua terdiri dari dua jejer (adegan) bobodoran dan dua jejer (adegan) perkelahian, serta babak ketiga terdiri dari dua jejer (adegan) dialog, satu jejer (adegan) bobodoran dan dua jejer (adegan) perkelahian, satu jejer (adegan) pidato kebudayaan.

\section{H. Penutup}

Tahapan selanjutnya, yaitu penutupan pagelaran wayang golek purwa ditandai dengan perkataan si Cepot, yaitu:

Hadirin semuanya, dikarenakan cerita pertunjukan wayang telah selesai, mari kita "sasanti reureuh bari mikir", artinya "persiapan untuk berhenti sambil berpikir", selanjutnya "lampah urang nu bade dongkap" artinya "prilaku kita yang akan datang", mari kita tutup dengan "kembang pinetik keur sedeng anyar sinebaran sari, tutup lawang $S i$ Go Ta Ka", artinya "semoga kita dapat memetik pelajaran dari inti/sari cerita, pintu Si Go Ta Ka /gapura kehidupan telah selesai". Dilanjutkan "merdeka, sekali merdeka tetap merdeka" artinya "setiap manusia yang konsisten akan dijauhkan dari segala marabahaya, didekatkan pada rezeki, dan dimudahkan dalam segala urusan".

Selanjutnya, pertunjukan wayang golek purwa diakhiri dengan instrumen musik dari grup pangrawit dengan sebuah lagu berjudul "Sabilulungan" yaitu lagu 
yang menunjukkan cerita yang menggambarkan permintaan pamit kepada panitia penyelenggara beserta penonton yang hadir menyaksikan pertunjukan. Setelah selesai instrumen tersebut, grup peralatan dibantu seluruh anggota sanggar seni MPP secara bersama-sama membereskan seluruh perlatan perlengkapan pertunjukan wayang golek purwa, sedangkan bapak dalang langsung naik ke mobil untuk pulang. Berakhirnya pertunjukan wayang sekaligus menjadi penutup seluruh acara hiburan pesta syukur laut nelayan Pamayangsari.

\section{Perubahan Fungsi Pertunjukan Wayang Golek Purwa}

Pada bagian analisis ini, hal berikutnya yang akan dibahas adalah 1) perubahan fungsi pertunjukan wayang golek purwa dari sakral ke profan 2) faktor penyebab terjadinya perubahan; serta 3) faktor pendukung berjalannya perubahan pertunjukan wayang golek purwa.

\section{Perubahan Fungsi Pertunjukan Wayang Golek Purwa dari Sakral ke Profan}

Untuk mendeskripsikan perubahan fungsi yang terjadi pada pertunjukan wayang golek purwa di pantai Pamayangsari Desa Cikawungading Kecamatan Cipatujah Kabupaten Tasikmalaya, peneliti akan menggunakan analisis data menggunakan pendekatan teori fungsionalisme dari Bronislaw Malinowski. Konsep Malinowski dalam (Koentjaraningrat, 1987: 180) melihat suatu kebudayaan manusia dari segi fungsinya yaitu merupakan segala aktivitas budaya yang dilakukan bertujuan untuk memuaskan naluri kebutuhan dasar manusia yang saling berhubungan.

Pada bab-bab sebelumnya penulis telah ungkap data awal mengenai fungsi dari pertunjukan wayang golek purwa. Untuk mempermudah proses analisis data, selanjutnya penulis akan mengelompokkan data lapangan ke dalam tiga kategori, yaitu periode awal dari tahun 1975 s.d. 1987, periode kedua dari tahun 1988 s.d. 2005, dan dari tahun 2006 s.d. sekarang menjadi data periode ketiga.

Fungsi pertunjukan wayang golek purwa pada periode pertama sebagai bagian dari pesta syukur laut yang bernilai sakral. Berikut penuturan bapak Aang (74 tahun):

Pada tahun 1975 sampai tahun 1987, menurut bapak saya yaitu abah Tanu, bahwa jenis pertunjukan wayang golek yang ditampilkan adalah wayang ruwatan, karena yang diinginkan oleh masyarakat selain bermaksud syukuran laut, juga punya tujuan lain yaitu ingin diselamatkan, oleh karena itu jenis wayang yang dipentaskan adalah wayang ruwatan. Sebelum pertunjukan wayang golek, bapak saya selalu mempersiapkan kemenyan dan sesaji yang lengkap, lalu disimpan pada nampan. Seingat saya pada pertunjukan wayang ruwatan itu, cerita yang dibawakannya adalah lakon Batara Kala, terus membahas kehidupan nelayan, menyebutkan larangan-larangan seperti ketika akan pergi melaut dilarang menginjak ombak pertama, terus pada pertengahan pertunjukan dalang membakar kemenyan, setelah itu wayang Batara Kala kesurupan, selanjutnya seluruh penonton harus diam, tidak boleh ada yang bergerak, berjalan kaki, apalagi tertawa, dan harus fokus menyaksikan sampai acara pertunjukan wayang selesai. Setelah selesai penonton beramai-ramai mengambil air yang sudah melewati proses ruwat, memang sebagian masyarakat percaya air tersebut untuk keselamatan.

Dari pernyataan tersebut menjelaskan fungsi pertunjukan wayang golek purwa periode pertama masyarakat ingin memenuhi kebutuhan dasar akan sistem kepercayaan, yaitu suatu kepercayaan akan 
keselamatan dari berbagai bala bencana, yaitu dengan ritual ruwatan. Ruwatan adalah sebuah tradisi yang selalu melibatkan unsur sesaji. Dengan adanya sesaji, maka fungsi pertunjukan wayang golek purwa periode pertama bernilai sakral.

Selanjutnya, pada periode kedua, masih berdasarkan hasil wawancara dengan bapak Aang (74 tahun) bahwa:

Pada tahun 1988 masyarakat nelayan tidak lagi mementaskan wayang ruwatan, sebab untuk mementaskan jenis wayang ruwatan itu memerlukan biaya yang sangat besar, tetapi di sisi lain masyarakat mempunyai keinginan agar pementasan wayang itu harus selalu diadakan, karena masyarakat nelayan sudah menganggap bahwa di antara jenis kesenian yang bisa memberikan tuntunan sekaligus tontonan/ hiburan adalah wayang. Wayang itu adalah kesenian buhun yaitu warisan dari nenek moyang, dalam hal ini ada sebuah istilah "kita wajib menghargai tatali paranggi kolot baheula". Jadi masyarakat nelayan tetap mementaskan pertunjukan wayang, akan tetapi jenis wayang yang akan dipentaskan dalam rangkaian acara syukur laut bukan wayang ruwatan. Selanjutnya dalam praktiknya masih menyertakan sesaji, karena hal tersebut merupakan kepercayaan sesepuh dahulu.

Dari pernyataan bapak Aang (74 tahun) mengenai fungsi pertunjukan wayang pada periode kedua yaitu sebagai kesenian buhun yang harus dijaga dan dilestarikan serta bersifat mistis dengan adanya sesaji, maka mengandung nilai kesakralan. Pendapat tersebut diperkuat oleh pernyataan bapak Sana Sopiana (38 tahun) yaitu:

Ketika saya masih duduk di bangku kelas dua SD (Sekolah Dasar), saya memang suka mengikuti rangkaian pesta syukur laut. Karena kan bapak saya abah Kancil adalah sesepuh nelayan, terlebih saya sendiri menyukai kesenian pertunjukan wayang golek. Seingat saya pada tahun 1992, acara syukur laut itu diisi dengan pertunjukan wayang golek purwa dan larung jempana yang berisi kepala kambing dengan beragam isian sesaji lainnya termasuk dalam wayang pun masih menyertakan sesaji, terus sesaji tersebut dikasihkan kepada dalang, karena ayah saya semasa hidupnya terhadap kepercayaannya masih kental.

Dari dua pernyataan narasumber di atas dapat diambil kesimpulan bahwa pada periode kedua yaitu dari tahun 1988 s.d. tahun 2005 sebagian besar masyarakat nelayan masih memiliki kepercayaan akan halhal mistis. Tetapi karena keterbatasan ekonomi, masyarakat akhirnya mengubah jenis pertunjukan wayang golek ruwatan diganti dengan wayang golek bukan ruwatan, tetapi masih terdapat unsur sesaji di dalamnya untuk memenuhi kebutuhan spiritual masyarakat. Maka, masyarakat melakukan aktivitas kebudayaan dengan menggelar pertunjukan wayang golek purwa yang disertai unsur sesaji di dalamnya. Dengan adanya sesaji, maka fungsi pertunjukan wayang golek purwa periode kedua pun bernilai sakral.

Sedangkan pada periode ketiga pertunjukan wayang golek purwa secara fungsinya telah mengalami perubahan dari fungsi pada periode awal dan periode kedua bernilai sakral berubah menjadi hiburan. Pernyataan tersebut berdasarkan hasil pengamatan penulis selama berada di lapangan bahwa kondisi kepercayaan masyarakat yang sekarang atau periode ketiga sudah berbeda dengan kondisi kepercayaan masyarakat pada periode pertama dan periode kedua seperti yang dipaparkan dua narasumber di atas. 
Penulis melihat sebagian besar kondisi kepercayaan masyarakat Pamayangsari sudah tidak lagi mempercayai adanya mitos Nyi Roro Kidul, dedemit dan sebagainya. Pernyataan tersebut berdasarkan pendapat sebagian masyarakat seperti penuturan bapak Sana Sopiana (38 tahun) selaku ketua Rukun Nelayan Pamayangsari:

Kalau menurut pendapat saya pribadi, bahwa isian sesaji seperti kepala kerbau, berbagai macam jenis makanan, dan minuman sebaiknya tidak dibuang ke laut atau dipersembahkan dalam pagelaran wayang golek. Coba dipikirkan dan dipahami kembali manfaat yang lebih baik, misalnya kepala kerbau tersebut kalau memang mampu, lebih baik dikasih ke fakir miskin, atau ke masyarakat yang lebih membutuhkan. Kemudian sesaji seperti tumpeng dipersembahkan kepada pohon, ke nenek moyang itu kan menurut saya pribadi sudah syirik.

Dari pernyataan di atas, dapat dilihat bahwa kondisi kepercayaan masyarakat sudah berubah. Perubahan selanjutnya tidak hanya pada kondisi kepercayaan, tetapi berdasarkan temuan data penulis di lapangan lebih ke pemenuhan akan kebutuhan dasar (naluri) manusia yaitu kondisi masyarakat sekarang yang menginginkan berbagai pertunjukan hiburan. Pada periode ketiga ini, sebagian besar masyarakat Pamayangsari menginginkan berbagai pertunjukan hiburan untuk mengisi pesta syukur laut.

Kondisi masyarakat seperti ini dapat dilihat dari jenis-jenis hiburan baik dari kesenian wayang golek purwa, maupun kesenian-kesenian lainnya serta berbagai permainan yang ditampilkan untuk mengisi pesta syukur laut. Seperti yang diutarakan bapak Sana Sopiana (38 tahun):

Pesta syukur laut itu dilaksanakan selama satu minggu berturut-turut. Hari pertama ada dangdutan, hari kedua perlombaan-perlombaan seperti tarik tambang, balap karung, dan sebagainya. Hari ketiga dan keempat turnamen volleybal, hari kelima pengajian Bapak KH. Burhanudin Marfu, hari keenam lomba Kasidah Modern, dan hari ketujuh pesta adat disertai penampilan berbagai kesenian daerah serta ditutup dengan pertunjukan wayang golek purwa bapak dalang Wawan Dede Amung S dari sanggar seni MPP (Munggul Pawenang Putra) Bandung.

Untuk memenuhi keinginan akan hiburan tersebut, maka masyarakat melakukan berbagai aktivitas kebudayaan salah satunya dengan menggelar pertunjukan wayang golek purwa yang fungsinya lebih ke hiburan.

\section{Faktor Penyebab Perubahan Fungsi Pertunjukan Wayang Golek Purwa dari Sakral ke Profan}

Setelah mengetahui dinamika dan perubahan fungsi pertunjukan wayang golek purwa, maka selanjutnya penulis akan mendeskripsikan temuan-temuan data lapangan mengenai faktor-faktor yang menyebabkan terjadinya perubahan fungsi pada pertunjukan wayang golek purwa pada pesta syukur laut di Pamayangsari Desa Cikawungading Kecamatan Cipatujah Kabupaten Tasikmalaya. Menurut Malinowski dalam (Koentjaraningrat, 1987: 180) kebudayaan itu adalah suatu kesatuan yang bulat dan tidak terpisah-pisahkan, dengan kata lain terintegrasi. Di dalam kesatuan yang bulat itu terdapat bagian-bagian atau unsurunsur yang saling berkaitan atau bahkan secara ekstrem dapat dikatakan saling bergantung unsur satu dengan yang lainnya.

Berdasarkan data lapangan yang berhasil penulis kumpulkan dan analisa, terdapat faktor-faktor yang menyebabkan terjadinya perubahan fungsi pertunjukan wayang golek purwa, faktor-faktor tersebut 
Fipih, Cahya, Neneng - Perubahan Fungsi Pertunjukan.....

saling berkaitan satu sama lain, yaitu sebagai berikut:

a. Berubahnya sistem kepercayaan masyarakat

b. Cara berpikir masyarakat modern

c. Kebutuhan sebagian masyarakat yang menginginkan hiburan

d. Konflik masyarakat

e. Bencana Alam Tsunami Cipatujah pada Tahun 2006

f. Pengaruh kebudayaan luar

\section{Faktor yang Mendukung Terjadinya Perubahan Fungsi Pertunjukan Wayang Golek Purwa}

Terjadinya perubahan fungsi pertunjukan wayang golek purwa dari sakral ke profan pada pesta syukur laut di pantai Pamayangsari Desa Cikawungading Kecamatan Cipatujah Kabupaten Tasikmalaya, tidak dapat dipisahkan dari faktor yang mendukung jalannya perubahan. Faktor tersebut, di antaranya: sponsor dan sejalan dengan visi misi kabupaten Tasikmalaya.

Dari uraian mengenai struktur pertunjukan dan perubahan fungsi pertunjukan wayang golek purwa di Pamayangsari dapat disimpulkan bahwa struktur pertunjukan wayang terdiri dari tiga tahap. Tahap pertama yaitu pra-pertunjukan/ persiapan merupakan tahapan mempersiapkan segala sesuatu baik dalam hal sarana dan pra sarana seperti boneka wayang, seperangkat gamelan,gedebog, tapak dara, jagat nagaraja, janturan, gugunungan, kecrek wayang, cempala, kotak wayang, dan pandel. Selanjutnya, mempersiapkan pelaku pertunjukan wayang seperti dalang dan grup pangrawit. Selanjutnya, pada tahapan persiapan ini panitia penyelenggara menampilkan sambutan-sambutan diantaranya sambutan atas nama ketua panitia, kepala desa, dan unsur Muspika.

Tahapan kedua dari struktur pertunjukan wayang golek purwa yaitu pementasan atau pertunjukan wayang, tahapan ini merupakan bagian inti dari pertunjukan wayang yang dibagi ke dalam tiga babak yaitu babak pembukaan, babak inti, dan babak penutupan. Selanjutnya tahap terakhir yaitu tahap penutup, merupakan tahapan yang diisi dengan penyampaian pesan-pesan moral dari dalang kepada penonton, selanjutnya diakhiri dengan instrumen musik sebuah lagu dengan judul Sabilulungan.

Kemudian pertunjukan wayang golek purwa pada upacara syukur laut di Pamayangsari telah mengalami perubahan fungsi yang asalnya bernilai sakral berubah menjadi profan. Berubahnya fungsi tersebut dikarenakan beberapa faktor seperti berubahnya sistem kepercayaan masyarakat, cara berfikir masyarakat modern, kebutuhan sebagian besar masyarakat menginginkan hiburan, adanya konflik di masyarakat, adanya bencana alam tsunami Cipatujah tahun 2006, dan adanya pengaruh dari kebudayaan luar. Selain faktor yang menyebabkan terjadinya perubahan fungsi tersebut, terdapat juga faktor pendukung seperti adanya sponsor yang mendanai seluruh kegiatan pesta syukur laut termasuk pertunjukan wayang golek purwa dan adanya himbauan/anjuran dari bupati Kabupaten Tasikmalaya terkait dihilangkannya sesaji.

\section{SIMPULAN}

Setelah penulis melakukan berbagai tahapan penelitian dengan pendeskripsian dan analisis substansi penelitian, maka dapat ditarik kesimpulan sebagai berikut.

1. Struktur pertunjukan wayang golek pada ritual syukur laut terdiri dari tiga tahap, yaitu tahap pertama adalah persiapan/prapertunjukan dengan mempersiapkan sarana dan prasarana, pelaku pertunjukan wayang, dan sambutan-sambutan. Tahapan kedua yaitu pementasan atau pertunjukan wayang yang dibagi ke dalam tiga babak, yaitu 
babak pembukaan, babak inti, dan babak penutupan. Selanjutnya, tahap terakhir yaitu tahap penutup, yaitu penyampaian pesan-pesan moral dari dalang kepada penonton.

2. Telah terjadi perubahan yang signifikan tentang fungsi pertunjukan wayang golek pada ritual syukur laut, yakni dari fungsi sakral ke profan dengan bukti realitas budaya sebagai berikut:

a. Pada tahun 1975-1987, fungsi pertunjukan wayang golek bernilai sakral, karena terdapat ritual ruwatan berfungsi untuk menolak datangnya bala bencana.

b. Pada tahun 1988-2005, fungsi pertunjukan wayang golek masih bernilai sakral, meskipun ritual ruwatan dihilangkan, tetapi sesaji masih dipertahankan. Fungsi sesaji yaitu sebagai bentuk persembahan kepada makhluk gaib seperti jin, dedemit, roh halus, dan sebagainya.

c. Pada tahun 2006-sekarang, fungsi pertunjukan wayang golek berubah dari sakral menjadi profan. Perubahan tersebut dikarenakan hilangnya unsur sesaji pada pertunjukan wayang dan keinginan masyarakat akan hiburan.

Demikian hasil simpulan yang dapat penulis deskripsikan, sebagai akhir dari tahapan penulisan hasil penelitian skripsi tugas akhir di Program Studi Antropologi Budaya.

Penulis berdasar pada data, hasil analisis, dan simpulan tersebut, maka sejumlah rekomendasi dapat diberikan kepada pihakpihak tertentu sebagai berikut:

\section{Kepada Masyarakat Kampung Pamayangsari}

Kepada masyarakat Kampung Pamayangsari, baik golongan tua maupun golongan muda agar menjaga budaya warisan dari nenek moyang. Bagi golongan tua agar memberikan pendidikan dan pengarahan yang sifatnya mengayomi golongan muda terkait warisan budaya, yaitu kesenian wayang golek purwa. Wayang golek purwa merupakan seni buhun yang penuh dengan makna filosofi kehidupan masyarakat Sunda. Bagi golongan muda agar menanamkan rasa ingin tahu terhadap budaya asli masyarakat Pamayangsari, sehingga menumbuhkan kesadaran untuk mengembangkan penyelenggaraan wayang golek purwa dan budaya lokal lainnya ke arah yang lebih baik.

\section{Kepada Organisasi Rukun Nelayan Pamayangsari}

Kepada organisasi Rukun Nelayan Pamayangsari agar setiap penyelenggaraan upacara syukur laut dilakukan evaluasi menyeluruh berbagai unsur yang terkait dengan pelaksanaan upacara syukur laut, tidak hanya sebatas merealisasikan keinginan masyarakat nelayan Pamayangsari. Tetapi, mengkaji lebih dalam mengenai bagaimana caranya supaya masyarakat sekitar lebih termotivasi untuk melestarikan, bahkan mengembangkan budaya tersebut.

\section{Kepada Sanggar Seni Desa Cikawungading \\ Kepada sanggar seni Desa Cika-} wungading agar lebih giat lagi dalam mensosialisasikan budaya lokal, caranya bisa menggunakan fasilitas media sosial seperti Facebook, Youtube, dan sebagainya. Sehingga mampu menarik animo perhatian masyarakat golongan muda dalam mengenal, mencintai, dan melestarikan budaya lokal.

\section{Kepada Pihak Pemerintah}

Kepada pihak pemerintah baik dari tingkat desa sampai tingkat pusat agar memperhatikan kelangsungan hidup masyarakat nelayan Pamayangsari, terkait bantuan perahu dan alat-alat melaut yang lebih canggih untuk meningkatkan produktivitas masyarakat nelayan Pamayangsari. Tidak hanya itu, pemerintah diharapkan agar membangun kembali pela- 
Fipih, Cahya, Neneng - Perubahan Fungsi Pertunjukan.....

buhan yang sebagian besar mengalami kerusakan akibat diterjang ombak yang besar dan tinggi.

\section{Untuk Penelitian Lanjutan}

Berdasarkan pada pengalaman peneliti ketika melaksanakan sebuah penelitian di lapangan, terdapat keterbatasan kondisi dimana fokus dari penelitian penulis yaitu pertunjukan wayang, ketika berada di lapangan penulis menemukan data mengenai jenis kebutuhan masyarakat akan kesenian yang begitu tinggi. Maka, penulis menyarankan untuk dilakukan penelitian lanjutan mengenai kesenian-kesenian daerah yang terdapat di Desa Cikawungading.

\section{DAFTAR PUSTAKA}

\section{Buku}

Ahmadi, Abu. (1997). Ilmu Sosial dasar, Ed Baru, Jakarta: Rineka Cipta.

Bogdan, Robert, dan Tylor. (1992). Pengantar Metode Penelitian Kualitatif. Penerjemah Arief Rujhan, Surabaya: Usaha Nasional.

Bungin, Burhan. (2012). Metodologi Penelitian Kualitatif, Jakarta: Raja Grafindo Persada.

Daradjat, Zakiah. (1985). Perbandingan Agama, Jakarta: Bumi Aksara.

Eliade, Mercia. (2002). Sakral dan Profan, Yogyakarta: Wan Dwi.

Endraswara, Suwardi. (2008). Metodologi Penelitian Kebdayaan, Yogyakarta: Gajah Mada University Press.

Hariwijaya. (2017). Metodologi dan Teknik Penulisan Skripsi, Thesis \& Disertasi, Jakarta: Elmatera.

Hedy, Cahya. (2011). Bandung(Puseur) Pedalangan Sunda dalam Dua Ratus Tahun Seni di Bandung, Bandung: Pusbitari Press.

Hedy, Cahya. (2016). Nilai, Makna, dan Simbol Dalam Pertunjukan Wayang Golek Sebagai Representasi Media Pendidikan
Budi Pekerti, Bandung. Panggung, 26 (2), 122.

Hidayat, Wahyu. (2019). Data Monografi Desa Cikawungading, Tasikmalaya.

Marsaid. (2016). Islam dan Kebudayaan: Wayang Sebagai Media Pendidikan Islam di Nusantara, Jurnal Kontemplasi, 4 (1), 60.

Masroer. (2015). Spiritualitas Islam Dalam Budaya Wayang Kulit Masyarakat Jawa dan Sunda, Jurnal Ilmiah Sosiologi Agama, 9 (1), 25.

Miles dan Huberman (1992). Analisis Data Kualitatif, Jakarta: Universitas Indonesia Press.

Muhammad, Nurdianah. (2013). Memahami Konsep Sakral dan Profan Dalam Agama-Agama. Substantia, 15 (2), 278279.

Mulyadi. (2005). Ekonomi Kelautan, Jakarta: PT Raja Grafindo Persada.

Pamungkas. (2008). Tradisi Ruwatan: Misteri dibalik Ruwatan, Yogyakarta: Narasi.

Pusat Bahasa. (2017). Kamus Besar Bahasa Indonesia, Jakarta: Gramedia Pustaka Utama.

Rosari, Renawati W. (2013). Kamus Seni Budaya, Surakarta: PT Aksara Sinergi Media.

Saepuloh. (2006). Buku Panduan Metodologi

Penelitian, Malang: Fakultas Syari'ah Bandung.

Setyobudi, I. (2020). Metode Penelitian Budaya (Desain Penelitian dan Tiga Model Kualitatif). Bandung: Sunan Ambu Press.

Solichin, Suyanto, dan Sumari. (2016). Ensiklopedi Wayang Indonesia Edisi Revisi Aksara B Jilid 2.

Suanda, A. Sapaat. (1993). Saresehan Pedalangan di Pasundan, Jawa barat: RRI Bandung, 1-15

Sugiyono. (2013). Metode Penelitian Kuantitatif, Kualitatif dan $R \& D$, Bandung: Alfabeta. 
Sunarya, I Ketut. (2012). Pendidikan Tinggi Seni Berkarakter Budaya Adiluhung Estafet Generasi Kreatif yang Berkelanjutan, Jurnal Pendidikan Karakter, II (2), 184.

Syam, Nur. (2005). Islam Pesisir, Yogyakarta: LkiS.

\section{Sumber Internet}

Calung. Diakses pada tanggal 29 Mei 2020, pukul 13.30 WIB, dari https://id.m.wiki pedia.org/wiki/calung_sunda/

https://sains.kompas.com/read/2016/07/18/072 94931/10.tahun.tsunami.pangandaran.t sunami.dahsyat.tanpa.isyarat.gempa?pa ge $=$ all/10 Tahun Tsunami Pangandaran, Tsunami Dahsyat Tanpa Isyarat Gempa. Diakses pada tanggal 27 Februari 2020, pukul 8.30 WIB.

Jaran Kepang Jawa Timur, Jaranan atau Kuda Lumping. Diakses pada tanggal 2 Agustus 2020, pukul 10.47 WIB, dari Kemeriahan Tradisi Syukur Laut di Pantai Pamayangsari Tasikmalaya. Diakses pada tanggal 22 Januari 2020, pukul 12.00 WIB, dari https://www.ini baru.id/tradisinesia/kemeriahan-tradisisyukur-laut-di-pantai-pamayangsaritasikmalaya/
Manajemen Keperawatan. Analisis Data Kualitatif. Diakses pada tanggal 2 februari 2020, pukul 11.00 WIB, dari http://elsye.staff.umy.ac.id/pengolahandata-kualitatif/

Pencak Silat Seni Bela Diri dari Indonesia. Diakses pada tanggal 29 Mei 2020, pukul 13.30 WIB, dari https://id.m.wiki pedia.org/wiki/pencak_silat/

Pesta Syukur Laut di Pantai Pamayangsari tanpa Kepala Kerbau. Diakses pada tanggal 24 Januari 2020, pukul 10.00 WIB, dari http://www.kabarindonesia. com/berita.php?pil $=26 \& \mathrm{jd}=$ Pesta $+\% 93$ Syukur\%94+Laut+di+Pantai+Pamayan gsari + tanpa + Kepala + Kerbau\&dn $=200$ 91228213857/

Wayang Golek. Diakses pada tanggal $30 \mathrm{Mei}$ 2020, pukul 10.00 WIB, dari https://id.m.wikipedia.org/wiki/wayang _golek/

Wildah, Adiba, Zahrotul. (2018). Sinkretisme Agama Kasus Ritual Baritan (Sedekah Laut) di Desa Asemdoyong Pemalang, UIN Jakarta, Indonesia, Jakarta. 